\title{
Learning through Play: A Serious Game as a Tool to Support Circular Economy Education and Business Model Innovation
}

\author{
Saskia Manshoven *(D) and Jeroen Gillabel \\ Unit Sustainable Materials Management, Flemish Institute for Technological Research, VITO NV, Boeretang 200, \\ B-2400 Mol, Belgium; jeroen.gillabel@vito.be \\ * Correspondence: saskia.manshoven@vito.be
}

Citation: Manshoven, S.; Gillabel, J.

Learning through Play: A Serious

Game as a Tool to Support Circular Economy Education and Business

Model Innovation. Sustainability 2021,

13, 13277. https://doi.org/10.3390/

su132313277

Academic Editor: Antonio Boggia

Received: 12 October 2021

Accepted: 26 November 2021

Published: 30 November 2021

Publisher's Note: MDPI stays neutral with regard to jurisdictional claims in published maps and institutional affiliations.

\begin{abstract}
Despite the increasing attention on circular economy at the policy level, the implementation of circular business models in companies is still limited. Many companies are put off by the apparent complexity to translate the general concepts of a circular economy into their business practice. This paper presents the development and testing of a simulation board game that aimed to address this gap between theory and business practice. The board game, Risk\&RACE, was developed with the purpose of enabling students and business executives to experiment with circular economy business models. The gameplay was tested with 120 users, and cognitive learning outcomes as well as learning dynamics were assessed using a survey. The results of the game workshops demonstrated that the game advanced the participants' awareness of the need for a circular economy, their understanding of basic circular economy principles, and their insight in opportunities and challenges of circular business models at the company level. When reflecting on the game as a learning tool, players highlighted its engaging and realistic nature and praised how it stimulated strategic thinking. Complementing the gameplay with a debriefing discussion afterwards encouraged players to reflect upon their newly gained insights, deepening their learning experience.
\end{abstract}

Keywords: circular economy; business model; serious game; entrepreneurship; education; game-based learning; simulation

\section{Introduction}

Over the past few years, the concept of circular economy has become an important ambition in European policy strategies, with the objective to keep resource consumption and environmental impacts within planetary boundaries [1] while boosting industrial competitiveness and job creation [2-4]. Companies play a key role in this transition [5].

An increasing number of organisations, start-ups, as well as existing companies have started to show interest in developing new products and services that fulfil circular economy ambitions [6]. While a multitude of successful case studies are reported on inspirational platforms [7-9], the implementation of circular business models in practice remains low $[10,11]$. Too often, circular economy is merely regarded as an approach to improve waste management, focused on increased recycling [12-14], while the implementation of more 'radical' forms such as reuse, product-service systems, or remanufacturing remains low in practice [15]. Nevertheless, case study research has proven that circular business models help companies to mitigate risks (e.g., reduce resource supply dependence, protect against price volatility), enhance competitiveness (e.g., by differentiating offerings, strengthening customer relations), and accelerate growth (e.g., reducing operating costs and creating additional revenues) [16].

This low adoption rate suggests that many companies still struggle to identify and realise circular business opportunities. Indeed, the reshaping of a traditional, linear business model into a circular business model requires a fundamental change in the way companies do business, i.e., how they create, deliver, and capture value $[17,18]$. Although it is widely 
acknowledged that business model innovation is crucial [19-21], general awareness about the business opportunities of circular economy business models is still low. While a large body of research has focused on barriers related to lacking technology, and social, cultural, organisational, regulatory, financial, and market-related barriers [11,22], Kirchherr et al. [13] pointed out that the impact of 'soft' cultural barriers such as a 'hesitant company culture' is greater than that of 'hard' technological barriers. This shows that there is a need for awareness building and education on circular economy principles and opportunities at the company level.

First of all, business leaders-especially among top management that have the power to allocate company resources $[5,6]$ - need to gain understanding of the competitive advantages and potential value generation opportunities of circular business models, as well as of their cost implications and potential risks [23,24]. In addition, since business model innovation is an iterative process of piloting and eventually scaling up, companies need to be encouraged to engage in low-risk experimentation [25]. However, a gap exists between the knowledge needed for the implementation of circular strategies in a business context and the means and availability of circular economy business education. Moreover, the lack of inclusion of circular economy education in business curricula also suggests that it is not seen as a 'serious business thing' by business schools [26].

Teaching about sustainability in general, and circular economy in particular, is challenging because it is a complex topic, building on multidisciplinary knowledge [27], and is rich in trade-offs, interdependencies, and feedback loops [28]. Recently, a multitude of tools, education programmes, and online courses have been developed to educate students, entrepreneurs, and the wider public about circular economy principles [29-31] and circular business model innovation [21,32]. However, a review of existing educational tools suggests that many tools lack a clear focus on circular business model innovation, or-if they do have this focus - remain unused in practice because they do not succeed in meeting the needs of business developers due to inadequate empirical testing in a company context [32].

Game-based learning tools are attracting attention as effective ways of transferring knowledge on complex topics to a broad audience [33]. Apart from transferring knowledge of concepts and principles, they are also able to teach skills, such as decision-making and problem solving $[34,35]$. Contrary to many traditional educational settings in which learners sit back and listen passively to an instructor, educational games focus on learningby-doing, engaging learners to explore and experiment under the guidance of a skilled facilitator or coach. While doing so, players get immediate feedback on their actions and decisions while operating in a safe environment [36]. Many authors also indicate that the use of games in education increase motivation and engagement in comparison with traditional teaching methods $[27,34]$. This makes games especially interesting to be used in the field of sustainability education. Although a few educational games exist in the field of circular economy [28,37], most are limited to raising awareness about resource challenges in general (why circular economy is needed), while the opportunities and implications of circular business models from a company perspective remain underexposed.

In this paper, we explored how the strategic, operational, and financial opportunities and challenges of circular economy strategies and circular business models can be conveyed to students and business executives by means of a business simulation game. The board game Risk\&RACE was developed for this purpose. While a first prototype was described by Whalen [38], the current paper reports on the final version and elaborated user testing among 120 participants in five workshops. The research presents insights into the nature of the learning outcomes that are achieved through a business simulation game, and how this learning tool encourages learners to actively experiment, reflect on, and discuss the advantages and challenges of circular strategies and external factors affecting business model innovation.

Section 2 provides a brief overview of the theory of game-based learning and describes the serious game Risk\&RACE. It explains the workshop setup and the methodology used 
for data gathering and assessing learning outcomes. Section 3 presents some observations and playing strategies during the game workshops, the key insights gained by the participants, and the self-assessments of their learning experience. Section 4 analyses the results from the surveys, discusses the learning outcomes that were achieved, and reflects on the merits of Risk\&RACE as a tool to teach circular economy and entrepreneurship. Finally, Section 5 summarises the main findings and makes some suggestions for further research.

\section{Materials and Methods: The Serious Game Risk\&RACE}

Risk\&RACE is a serious game that was developed to educate students and professionals about circular economy. A review of existing games in the field of circular economy and sustainability [28,37] suggests that these games predominantly focus on the overall resource challenges and sustainability issues that prompt the need for a circular economy, lacking any attention to the operational and financial implications of adopting circular strategies and circular business models at a company level [38]. Targeting this gap, Risk\&RACE is a simulation game, covering the topic of circular economy from a company perspective, including basic principles of company management with a special focus on the operational and financial opportunities and challenges related to the adoption of circular business models. Secondly, Risk\&RACE is a fully fledged, non-digital board game, in contrast to most serious games in education that are digital games and videogames [39-42]. While the use of board games in sustainability education has been hardly studied, some researchers have theorised that the handling of tangible game pieces on a physical game board has a positive effect on learning due to increased engagement, better understanding of game mechanics, and visualisation of the effects of player decisions, as well as encouraging social interactions and discussion around the game table [43].

Section 2.1 provides a brief overview of the theory underpinning game-based learning and serious games. Section 2.2 describes the serious game Risk\&RACE, its projected learning goals, and how circular economy strategies and circular business models are embedded in the game mechanics. Next, in Section 2.3, the workshop setup is described, while Section 2.4 presents the data collection method and the analysis approach that were used to assess the game's learning effects.

\subsection{Game-Based Learning and Serious Games}

The purpose of game-based learning is to educate players by embedding learning outcomes in game content, creating a 'serious game' that is focused on engaging the user to achieve predefined objectives, promoting learning and behavioural change, rather than mere entertainment $[33,44]$. In the past few decades, there has been a proliferation of research and review articles on the design and use of serious games in higher education as an alternative to traditional teaching methods $[33,42,45,46]$, and also in the field of sustainability education $[27,37,47,48]$. Gamification principles such as achievable goals, progression paths, strategy options, immediate feedback, levels, points, rewards, competition, and cooperation encourage players to take on different roles, experiment with different options, and reflect on their choices and behaviour [48,49]. It was shown that by offering achievable goals and manageable tasks in a simplified and attractive game environment, player motivation and learning outcomes can be improved [50,51]. Intrinsic motivation can be enhanced by offering challenges, while triggering curiosity and fantasy, for example, by using a captivating narrative [52]. Competition has often been suggested to act as a motivational trigger, although some studies report negative emotional effects and distraction from learning [53]. Collaboration in teams, on the other hand, while not significantly adding to motivation, could advance players' learning by facilitation discussion [54]. Effective learning benefits from activities that provide immediate feedback and encourage active experimentation and problem-solving [55]. As games are able to combine these aspects that provoke motivation and learning, they make interesting tools to be used in education. 
Many theoretical foundations are used to study game-based learning [50]. Popular theories are self-determination theory (i.e., evoking feelings of autonomy, competence, and relatedness) [56], flow theory (i.e., promoting engagement in an activity, rendering it intrinsically rewarding to pursue) [57], and constructivist learning theory (i.e., building knowledge by linking new insights to prior knowledge and real-world scenarios through experimentation, problem-solving, and self-reflection) [58]. By intentionally incorporating certain elements and mechanics in a serious game design, a broad variety of cognitive, affective (motivational and behavioural), motoric, and communicative learning outcomesor a combination thereof-can be achieved [50,59].

\subsection{RiskERACE Learning Goals and Game Mechanics}

Simulation tools are especially suitable to demonstrate and model the systemic complexity of circular economy and its multifaceted challenges, interactions, and trade-offs [47]. The board game Risk\&RACE was designed as a business simulation game, incorporating a selection of elements that are fundamental to running a production company (e.g., employees, material and product stocks, sales strategies) against the narrative of a real-world scenario of external factors (e.g., resource scarcity, market forces, technological developments, policy changes) (Figure 1). The challenge players face is to develop a business strategy to maximise their company value in the timeframe of 10 rounds, representing 10 years. To improve their company's performance, players have a choice of investment options including circular economy strategies (e.g., recycling, reverse logistics) and sales strategies (e.g., direct sales, pay-per-use system). Throughout the gameplay, players collaborate in a team, while competing against other teams, under the guidance of a game facilitator. The game is highly visual, using tangible game pieces to represent employees, materials, and products, and showing physical material flows as well as potential strategic pathways on the game board to support players' decision making.

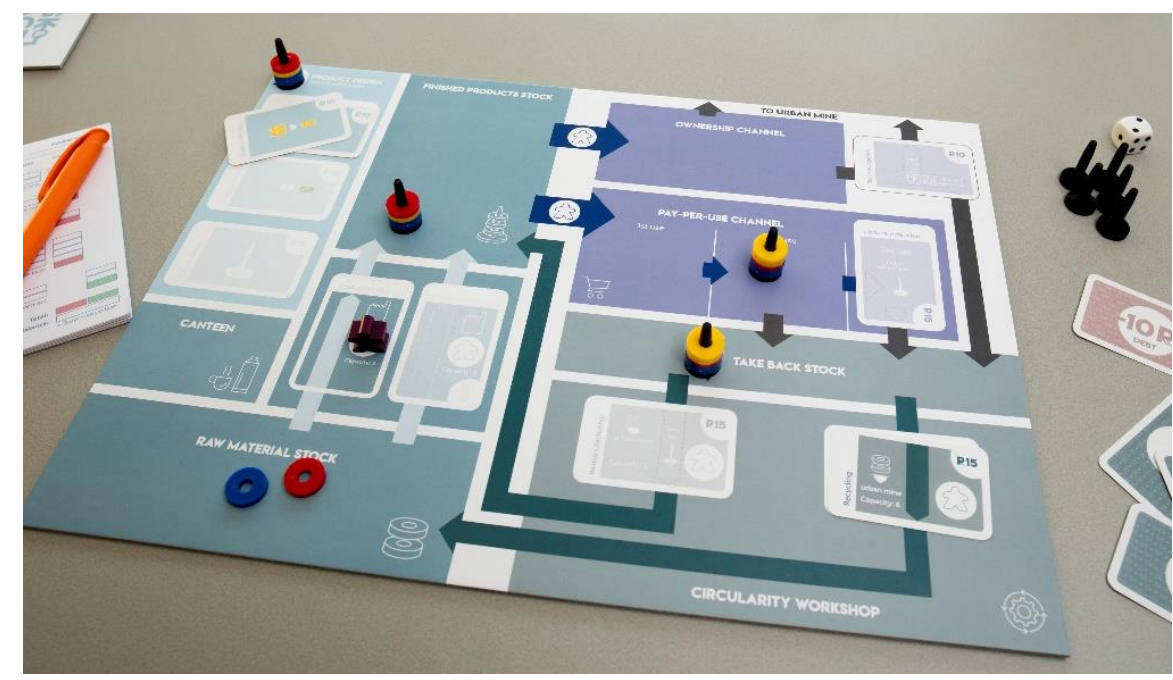

Figure 1. Risk\&RACE board game-player's board.

A detailed description of the gameplay, including a list of the investment options and their embodiment in the game mechanics is supplied in Appendix A.

The incorporation of dedicated learning goals makes Risk\&RACE into a serious game. The intended learning outcomes are mostly cognitive (i.e., understanding circular economy concepts). The learning goals that Risk\&RACE aims to convey to the players are threefold, linking to the why, what, and how of implementing circular economy strategies at a company level. After playing the game, players should be able to:

Goal (1) Understand the external pressures that challenge the linear economy, urging for a shift to a circular economy. External pressures are factors or situations out of the control of individual companies that influence business profitability, market strategy or 
product requirements, forcing a company to take actions to overcome these pressures [18]. In the game, external pressures are related to (1) resource challenges, such as depletion, supply risks and price volatility; (2) societal trends, such as an increased interest in servicebased product offerings; (3) technological developments, such as eco-friendly materials or improved recycling technology; or (4) policy measures, such as environmental regulations [60]. These pressures invite players to think about 'Why is it important to shift to a circular economy?'

Goal (2) Explain the principles of various circular economy strategies to make a company circular, including their advantages and disadvantages. Circular economy strategies are practices that aim to mitigate these resource challenges by applying circular economy principles, such as circular product design, lifetime extension, take-back, recycling, or remanufacturing $[10,61,62]$. They provide an answer to the question 'What needs to be done to make products circular?' These strategies are represented by the investment options that are available to the players throughout the game.

Goal (3) Reflect on how circular business models can contribute to a company's resilience and profitability, as well as the barriers to their implementation. By discussing the financial and business side of circular economy, players reflect on the question 'How can circular business models contribute to a successful business?'

Apart from cognitive learning goals, the game design deliberately intended to nourish players' motivation and encourage them to reflect on their behaviour, which are regarded as affective learning goals [50,59]. Gamification elements incorporated in Risk\&RACE include an engaging narrative of unexpected events, which confronts the players with challenges while triggering curiosity and fantasy [52]. The variety of possible game choices and strategic investment options allows players to decide on different strategic pathways, in line with self-determination theory [56]. Feedback is provided by the game in the form of financial revenues or costs (cash or debt), recovered or lost resources (material stock), and reusable products (take-back stock). The competitive elements of earning money and scoring the different teams at the end of the game aim to create engagement and excitement and add to the social interaction, in line with flow theory [57]. In-game learning processes rely on active experimentation with combining different strategies, observation of the strategies of other players, strategy discussions with teammates, frequent strategy changes in response to events, and linking new insights to existing prior knowledge and real-world examples, guided by the facilitator. As such, the Risk\&RACE game deploys elements of constructivist learning theory [58].

Figure 2 indicates how the investment options are part of the complex dynamic of multiple feedback and feedforward loops used to simulate business operations and external events impacting the business. The main challenge during the serious game developmentas also highlighted by de la Torre et al. [47]—was finding a balance between creating a realistic narrative (e.g., activities, market dynamics, policy constraints, environmental constraints, technological solutions) and managing the game's complexity (e.g., rules, number of decision options, game elements) in order to maintain intuitive, enjoyable gameplay.

\subsection{Workshop Setup}

To study the learning effects of Risk\&RACE, five workshops with different user groups were set up (Table 1$)$. The first cohort $(n=59)$ consisted of undergraduate engineering students at University College London who played the game as a seminar activity within a course on waste and resource management. The second cohort $(n=12)$ consisted of master students in business engineering at the University of Hasselt who played the game as a seminar activity within a course on business development. A third cohort $(n=11)$ consisted of company executives and entrepreneurs in the context of a business management course on 'Circular entrepreneurship', while a fourth cohort $(n=22)$ consisted of a group of sustainability advisors from the banking sector, during a strategic team building activity. Finally, a fifth cohort $(n=16)$ consisted of a mix of students and young professionals from 
different areas and backgrounds, participating in an educational weekend on 'innovative working formats for sustainability', aimed at scouting youth leaders.

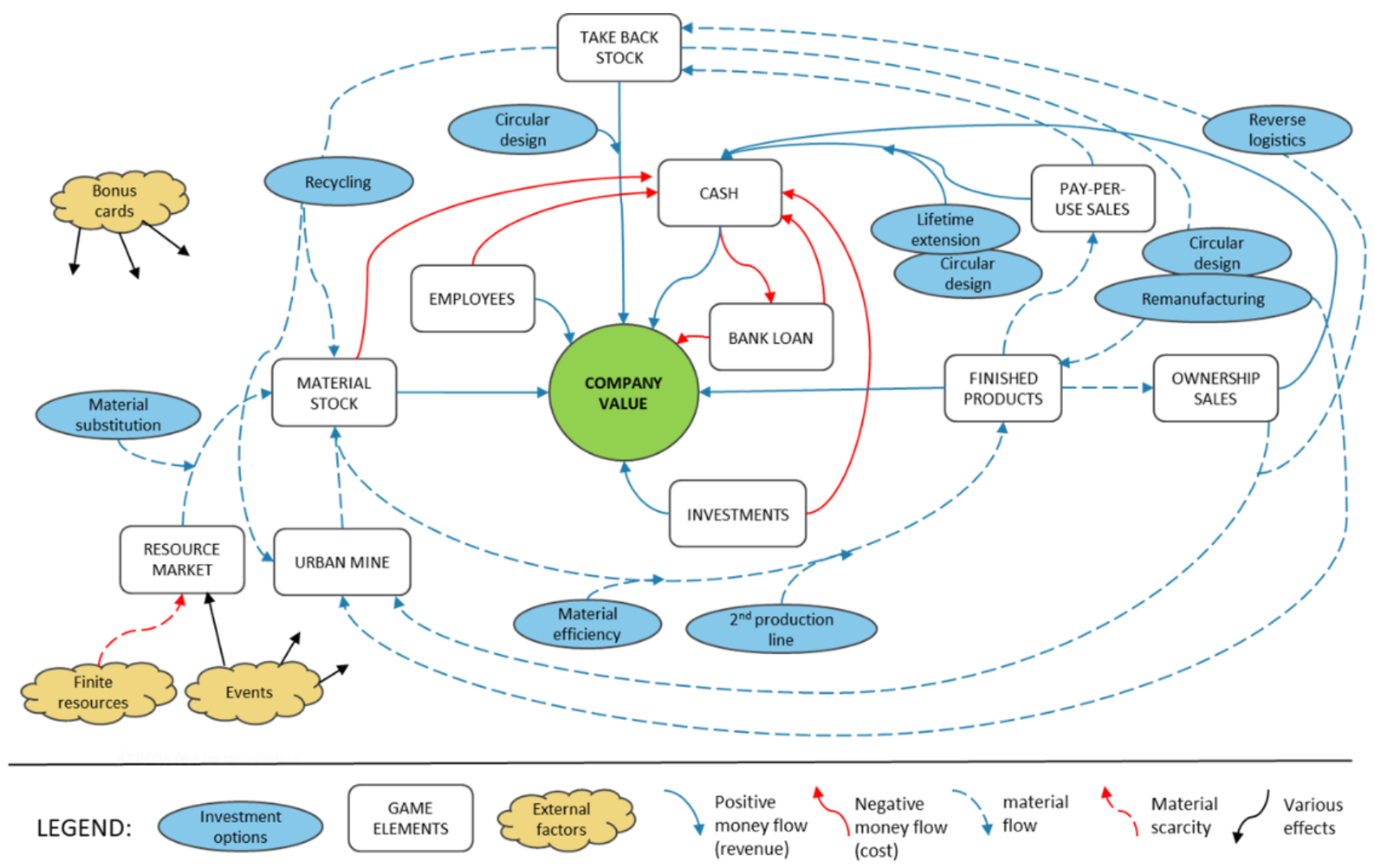

Figure 2. Feedback and feedforward loops in the Risk\&RACE game mechanics.

Table 1. Testing setup.

\begin{tabular}{ccccccc}
\hline & Cohort 1 & Cohort 2 & Cohort 3 & Cohort 4 & Cohort 5 & Total \\
\hline User group & Engineering & Business & Executives and & Financial & Mixed \\
Moderation & students & students & entrepreneurs & advisors & Per table \\
Number of participants & 59 & Per table & Per table & Per table & 22 & 16 \\
Completed surveys & 22 & 12 & 11 & 11 & 11 & 63 \\
Response rate & $37 \%$ & 12 & $64 \%$ & $50 \%$ & $69 \%$ & $53 \%$ \\
\hline
\end{tabular}

In all settings, players played in teams of two. The game sessions of cohorts 2, 3, 4 and 5 were supported and moderated by a dedicated game facilitator for each table, who provided explanation and guidance during the game. The facilitators had a background in circular economy and received training about the Risk\&RACE game and its mechanics prior to the workshops. The game tables of the (larger) cohort 1 were collectively instructed by an experienced lead moderator and two assistants, while the practical game moderation at each individual table was provided by a student volunteer with no prior knowledge about the Risk\&RACE game. The participants did not receive any formal instruction about circular economy prior to the game session. In all testing groups, the same scenario (narrative of events) was used. After the game, a 30-min debriefing was led by the game moderator. During the debriefing, the teams were asked to reflect on their investment strategy, their business decisions, and to what extent they were affected by unexpected events. In a group discussion, players were invited to share their individual learning outcomes, while the moderator's role was to feed observations from the game into the discussion to ensure accurate conclusions and to support the players in connecting their game learning outcome to real-world examples. 
After the workshop, the participants were asked to complete a post-game survey to assess their learning, on a voluntary basis. A total of 63 players submitted a completed survey.

\subsection{Data Gathering and Analysis}

Data were gathered from two main sources during the game workshops: game observations and post-game surveys.

\subsubsection{Observations}

During the gameplay, the strategic decisions of the players, such as investment choices and sales strategy, were observed by the moderators. During the debriefing after the gameplay, the players were encouraged to articulate and discuss the rationales behind their decisions with the group. These insights were used to identify and clarify different player strategies.

\subsubsection{Post-Game Surveys}

The post-game survey consisted of three parts. A first set of matrix questions invited players to make a brief self-assessment of their learning of relevant concepts. A second open question asked players to list their key learning outcomes ('eye openers') in a free format. A final set of three open questions asked about the player's general appreciation of the game as a learning tool, including affective (motivational and behavioural) aspects of learning. The post-game survey questions are provided in Appendix B.

The answers to the self-assessment matrix were analysed quantitatively, while the answers to the open questions were analysed using a qualitative approach involving a combination of deductive and inductive coding in order to make the free format answers suitable for analysis [63].

When reading through the 'eye-openers' that were reported by the players, the words or phrases in the written statements were labelled with a limited set of codes that reflect their content. As the total amount of statements was relatively limited $(n=130)$, coding was carried out manually. A two-step coding procedure was utilised. In a first round of coding, the statements from all cohorts were sorted according to three pre-defined themes, representing the three intended cognitive learning goals: (1) external pressures, (2) circular economy strategies, and (3) business models and entrepreneurship. Statements that included aspects of more than one learning goal were assigned all relevant codes. In a second round of coding, a specific set of codes was developed for each of the three themes, using inductive coding, i.e., starting directly from the individual statements. By representing the detailed content of the statements in tailor-made codes, the specific learning outcomes that players achieved could be grouped in subthemes and analysed in a structured way, while keeping as close as possible to the original data.

The questions that assessed players' appreciation of the game as a learning tool were analysed using an inductive coding system. A first set of codes was developed after the analysis of the answers of cohort 1 and utilised to code the statements of cohort 2 . When needed, codes were added or rephrased, and the new set was used to analyse the answers of cohort 3 and supplemented if needed. Finally, the resulting set of codes was then reapplied to the surveys from all cohorts to perform the final coding.

\section{Results}

The following sections present a brief observation of the game sessions and the results of the surveys. Following the testing sessions with the five cohorts, a total of 63 completed surveys were collected from a total of 120 participants (response rate of $53 \%$ ). In the case of cohorts 1 and 4, the players were allowed to complete the survey online in the two weeks after the game session, while in cohorts 2,3 , and 5 the surveys were completed directly after the gaming session, leading to a much higher response rate (Table 1). 


\subsection{Observed Player Strategies}

In the first introductory round, players were guided in their actions in order to introduce them to the basic game actions of buying resources, producing products, and selling them to the market. This approach sets them off in a traditional linear way of 'takemake-dispose'. From the second round onwards, players could make their own strategic decisions by selecting actions and choosing from the different investment options. By observing player investment decisions during the gameplay and discussing these decisions during the debriefings, different investment strategy typologies could be identified that were used by players in response to the presented game scenario.

Across all workshops, the two main dimensions that were observed to characterise players' game strategies were their choice of sales model (direct sales or pay-per-use) and whether or not they decided to invest in circular product design. These choices seem to reflect the players' pre-existing views on business profitability (short term profits versus long term profits) and product innovation (radical innovation by fundamentally rethinking and redesigning their products versus incremental innovation by pursuing a path of increasing efficiency and optimisation).

By combining these two dimensions, four key game strategy typologies emerge, as can be seen in Figure 3. Within each typology, a typical order of investments is made, following an underlying rationale. During the game, some players were observed switching from one business strategy to another.

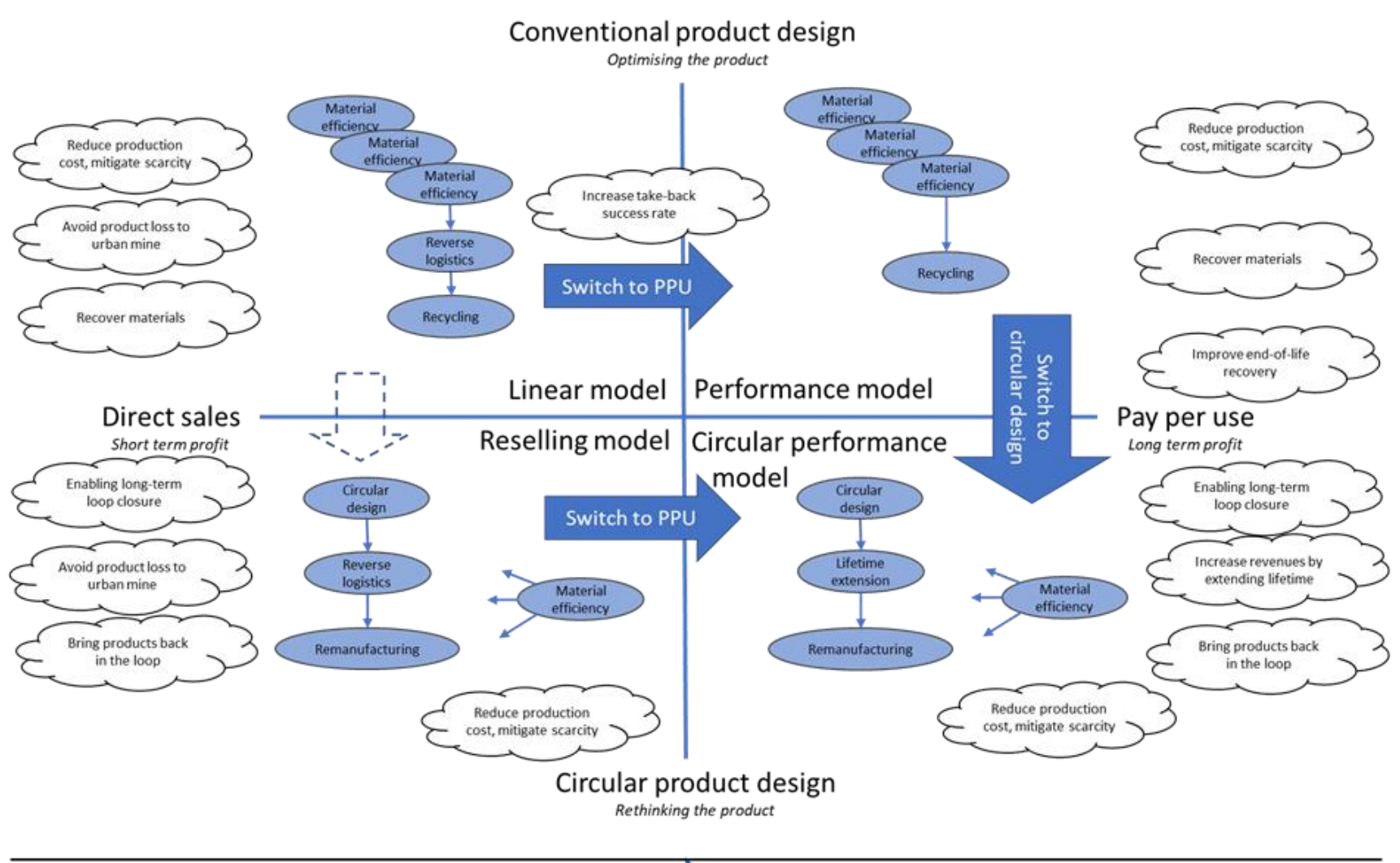

Legend: $\overbrace{\substack{\text { Investment } \\ \text { option }}}^{\begin{array}{c}\text { Underlying } \\ \text { rationale }\end{array}} \overbrace{\text { Dimension change }}$

Figure 3. Typology of key game strategies and player considerations, based on workshop observations.

The linear model (top left in Figure 3) is rooted in the 'take-make-dispose' paradigm, and assumes that virgin resources are abundantly available and easy to source, relying on manufacturing at the lowest possible cost, direct selling, and cheap disposal [6]. Players that use this paradigm keep a conventional product design and optimise their profitability by increasing material efficiency and selling through direct sales driven by direct revenues. 
However, when materials become scarcer and more expensive, a strategy based on resource efficiency no longer suffices to guarantee business continuity. Additionally, after a few rounds, many players realised that they were fully dependent on the availability and price of materials in the market. As a result, some players tried to recover materials by investing in reverse logistics and recycling (which is the only option for conventionally designed products). Notably, material losses from recycling are considerable in the case of products that are low in material content due to a fully optimised strategy of resource efficiency. Additionally, the recycled materials need to pass through the full production process to deliver new products, slowing down the loop. Other players shifted to a pay-per-use system in order to keep products within their control and avoiding product loss to the urban mine.

Motivated by the learning that products sold through direct sales end up as waste, or simply driven by curiosity, a second group of players engaged in the performance model (top right in Figure 3) by selling through pay-per-use, the game's representation of a service system. Choosing this strategy early in the game is indicative of a long-term vision driving business decisions. As in the linear model, players typically start with investing in resource efficiency to reduce production costs and may pursue this strategy for several rounds. Since the product design is still conventional, lifetime extension is not an option and players had no choice but to invest in recycling to recover part of their resources. At that point, it became obvious to most players that they could only achieve the full potential of their pay-per-use system by enabling lifetime extension and remanufacturing, two strategies that require products to have a circular design. Indeed, while pay-per-use systems are often regarded as enablers of sustainability and circularity $[64,65]$, they can only achieve true circularity when deliberately designed to do so [12].

A third group of players (bottom left in Figure 3) kept to traditional product sales to gain short-term revenues, but chose to invest in circular design circular as a way to enable remanufacturing and reselling at end-of-life, exploiting the residual product value [6]. Take-back is carried out through reverse logistics, with its inherent uncertainty. While an unsuccessful take-back attempt is always a painful experience for the player involved, most players seemed to consider it especially regrettable when it concerned a circular product, implying this kind of product is regarded as having 'higher value'. In order to increase the take-back rate, players often switched to a pay-per-use sales strategy at a certain point. Material efficiency investments were gradually added along the way to save on materials and production costs.

Finally, players focusing on circular performance (bottom right in Figure 3) combined circular product design with a shift to a product-service system from the start. The profitability of pay-per-use was boosted by extending product lifetime, while the guaranteed take-back complemented with remanufacturing allowed players to reintroduce their products into the market fast. In the event of a resource scarcity scenario, this strategy is bound to prove the most successful in the long run, provided players started using it early enough for it to unfold completely within the 10 rounds of the game. This strategy requires a lot of up-front investments that force players to get into debt, but that eventually will create a closed loop of product reuse and sustained revenues, almost independent of the resource availability in the market. Resource efficiency measures can be added throughout the gameplay to reduce costs and recover resources from the remanufacturing process. As the necessary order of these investments (first circular design, then life-time extension; using pay-per-use while it is less profitable than selling) does not yield benefits in the short term; only players that used a long-term vision and carefully analysed the connections between the different strategies at the start of the game chose this route.

In the resource-constraint scenario that was used in the workshops described in this paper, most players ended up working towards the 'Circular performance model' by the end of the game. As the profits of this model accrue in the long term, it is those players who embarked on this route the earliest who were most likely to win the game, while late 
adopters still struggled to get their products to complete their loops and reap the benefits of remanufacturing.

\subsection{Reported Key Insights}

After the game, players were asked to report which main insights (or 'eye-openers') they experienced. Since many respondents reported multiple eye-openers, a total of 130 statements was collected. The statements are diverse and multi-faceted. They include general statements on the wastefulness of the linear economy and the potential of the circular economy to solve resource challenges, detailed learning outcomes on specific circular strategies, as well as insights related to entrepreneurship in general or the implementation of circular business models in particular. To structure the responses, the statements were coded according to three themes: External pressures, Circular strategies, and Business models and entrepreneurship. Table 2 provides an overview of the number of statements that can be classified in each theme across the different cohorts. It should be noted that statements that make reference to multiple themes are counted for each, which explains why the percentages do not add up to $100 \%$.

Table 2. Number of statements on 'eye-openers' classified per theme.

\begin{tabular}{cccccccc}
\hline Code & $\begin{array}{c}\text { Cohort 1 } \\
(\boldsymbol{n}=\mathbf{4 3})\end{array}$ & $\begin{array}{c}\text { Cohort 2 } \\
(\boldsymbol{n}=\mathbf{3 4})\end{array}$ & $\begin{array}{c}\text { Cohort 3 } \\
(\boldsymbol{n}=\mathbf{1 5})\end{array}$ & $\begin{array}{c}\text { Cohort 4 } \\
(\boldsymbol{n}=\mathbf{1 9})\end{array}$ & $\begin{array}{c}\text { Cohort 5 } \\
(\boldsymbol{n}=\mathbf{1 9 )}\end{array}$ & $\begin{array}{c}\text { Total } \\
(\boldsymbol{n}=\mathbf{1 3 0})\end{array}$ \\
\hline External pressures & 12 & 0 & 0 & 3 & 2 & $17(13 \%)$ \\
\hline Circular strategies & 14 & 20 & 9 & 4 & 7 & $54(42 \%)$ \\
\hline Business models and entrepreneurship & 25 & 17 & 11 & 13 & 12 & $78(60 \%)$ \\
\hline
\end{tabular}

The following sections give a detailed overview of the players' reported key insights for each theme and subtheme. Individual example statements are provided in Table 3.

\subsubsection{External Pressures-Why Is Circular Economy Important?}

In $14 \%$ of the statements, eye-openers referred to external pressures, challenges, or events that illustrate the need to shift from a linear towards a circular economy (Table 2). The number of statements per subtheme are provided in Table 3 , including examples.

In Risk\&RACE, the predominant external pressure is resource depletion. Five statements mentioned the challenge of finite materials, resource depletion, and the associated supply risks (e.g., E1.3). Some complemented their statements by mentioning potential solutions, such as using recycled materials or adopting more resource efficient processes (e.g., E1.4).

Ten statements referred to the burden of uncertainty and sudden shocks that can be caused by market dynamics, policy changes, or resource constraints (e.g., E5.2). Some mentioned that a more circular business model can make a business less vulnerable to resource supply disruptions and more resilient against market fluctuations (e.g., E1.9).

Two statements referred to the wastefulness of a linear economy (E1.1), proposing the circular economy as a solution to reduce waste generation (E1.2).

\subsubsection{Circular Strategies-What Needs to Be Done to Make Products Circular?}

During gameplay, players became familiar with the different circular principles and strategies and how they influence production costs, product and resource flows, and endof-life options. In the eye-openers that players reported after playing, $37 \%$ of all statements involved a learning outcome or insight about one or more of the circular strategies included in the game (Table 2). The number of statements per subtheme are provided in Table 3, including examples. 
Table 3. Codes and example statements per theme, divided into sub-themes.

\begin{tabular}{ccc}
\hline Themes \& Subthemes & $\begin{array}{c}\text { Number of } \\
\text { Statements }\end{array}$ & Example Statements * \\
\hline External Pressures & 5 & $\begin{array}{c}\text { Resources deplete quickly and they are hard to obtain after that. (E1.3) } \\
\text { The minute the resources ran out you realise that you've got to be efficient and take } \\
\text { better care of the available raw materials. (E1.4) }\end{array}$ \\
\hline $\begin{array}{c}\text { Resource depletion } \\
\text { Uncertainty and } \\
\text { shocks }\end{array}$ & 10 & $\begin{array}{c}\text { Good intentions clashed with practical hurdles and market fluctuations. (E5.2) } \\
\text { A more circular economy is more resistant to market changes. (E1.9) }\end{array}$ \\
\hline $\begin{array}{c}\text { Waste generation } \\
\text { The end-of-life waste grew rapidly and it was a shock to see so much waste piling } \\
\text { up so quickly after one use. (E1.1) }\end{array}$ \\
Less waste was created with the circular economy. (E1.2)
\end{tabular}

\begin{tabular}{c}
\hline Circular strategies \\
Reduce material \\
use
\end{tabular}

First you have to optimise existing manufacturing by reducing the use of basic
materials to create additional cash flow. (E3.3)
Resource efficiency
Resource efficiency increases had a smaller effect than I imagined. (E3.1)
I realised that recycling is a good option only in an early stage, when resource efficiency is not too high. (E1.17)

\begin{tabular}{|c|c|c|}
\hline Recycling & 16 & $\begin{array}{l}\text { Recycled materials are very profitable in the lacking resources scenario. (E1.5) } \\
\text { By going for recycling, you lose resources and you need to start production from } \\
\text { scratch. (E2.5) }\end{array}$ \\
\hline Remanufacturing & 9 & $\begin{array}{l}\text { The smaller efforts required to re-introduce refurbished items compared to } \\
\text { recycled. (E3.5) } \\
\text { Recycling is good, remanufacturing is better. (E2.8) }\end{array}$ \\
\hline Circular design & 8 & $\begin{array}{l}\text { A product has to be designed in circular way beforehand. (E2.10) } \\
\text { Products need to be adaptable. (E2.9) }\end{array}$ \\
\hline Lifetime extension & 4 & $\begin{array}{l}\text { If you go for pay-per-use, make sure you can extend the contract as many times as } \\
\text { possible. (E2.18) }\end{array}$ \\
\hline $\begin{array}{l}\text { Multiple circular } \\
\text { options }\end{array}$ & 4 & [There are] many different ways/strategies to 'go circular'. (E3.7) \\
\hline $\begin{array}{l}\text { Keeping products in } \\
\text { the loop }\end{array}$ & 3 & It's more worthwhile to figure out how to keep products than make more. (E1.24) \\
\hline Reverse logistics & 1 & Reverse Logistics can be a good strategy but with a more uncertain outcome. (E3.8) \\
\hline Substitution & 1 & Biodegradability does not equal sustainability. (E5.8) \\
\hline \multicolumn{3}{|c|}{ Business models and entrepreneurship } \\
\hline $\begin{array}{c}\text { Investments and } \\
\text { costs }\end{array}$ & 27 & $\begin{array}{l}\text { It takes a lot of investment in the beginning. (E3.13) } \\
\text { Investments are long term, don't panic if you need to take on debt. (E2.24) }\end{array}$ \\
\hline $\begin{array}{l}\text { Cost reduction and } \\
\text { profitability }\end{array}$ & 27 & A circular model can be more profitable than a standard model. (E2.25) \\
\hline $\begin{array}{l}\text { Long term planning } \\
\text { and strategy }\end{array}$ & 22 & $\begin{array}{l}\text { Long-term planning is key. If we risked early enough to invest in circular design, we } \\
\text { would have saved a lot of materials and time wasted to recycling. (E1.22) }\end{array}$ \\
\hline $\begin{array}{l}\text { Operational } \\
\text { complexity }\end{array}$ & 11 & $\begin{array}{l}\text { It's rather difficult to establish from the start an optimal circular economy } \\
\text { strategy. (E4.15) } \\
\text { A lot of work and effort is needed to change your system. (E5.16) }\end{array}$ \\
\hline Pay-per-use & 10 & $\begin{array}{l}\text { Direct sales are tempting, but [pay-per-use] contracts can be more valuable. (E2.23) } \\
\text { The benefit is not experienced right away. It's easiest to always sell and acquire cash } \\
\text { early enough but then it does not pay off in the long term. (E1.28) }\end{array}$ \\
\hline Taking risk & 9 & $\begin{array}{l}\text { One should not hesitate to take risks when launching a start-up. (E4.17) } \\
\text { Keep an expense deposit for emergencies. (E1.41) }\end{array}$ \\
\hline Collaboration & 1 & Cooperation/partnership is key. (E4.16) \\
\hline Marketing & 1 & Marketing is very important, but it is not embodied in the game. (E3.15) \\
\hline
\end{tabular}

* Code between brackets refers to the statements identifier; the first number corresponds to the cohort. 
The overarching aim of all circular strategies is to reduce resource use. Seven statements mentioned the need to reduce resource consumption, which has the economic benefit of reducing production costs (e.g., E1.15), while eight statements put resource efficiency forward as an important ambition. Two statements, reported by business executives in cohort 3, stressed that reducing the amount of materials per product should be regarded as a priority action. One explicitly regarded this as an optimisation of the existing (linear) system due to cost reduction (E3.3). Still, one statement drew attention to the fact that resource efficiency may not be enough to overcome the challenges of resource scarcity (L3.1), while another statement highlighted the trade-off between increased material efficiency of products and a less viable recycling at end of life (E1.17).

Sixteen players mentioned recycling in their key learning outcomes. Some mentioned the merits of recycling in tackling resource scarcity (e.g., E1.5), while others focused on the inherent material losses associated with recycling, and the need for new production from scratch (e.g., E2.5). In eight statements, the strategy of remanufacturing was considered beneficial as it enabled players to reintroduce products very quickly into the market with little resource loss (e.g., E3.5). Some explicitly compared recycling with remanufacturing/refurbishing, pointing out that the latter are more successful in retaining product value and materials (e.g., E2.8).

Seven statements highlighted that products need to be deliberately designed with circularity in mind. Some mentioned modularity or adaptability as an example (e.g., E2.9).

Four statements put forward lifetime extension of products as a profitable strategy, especially in combination with a pay-per-use system (E2.18).

Four statements mentioned the myriad of circular strategies that are available, acknowledging that there is no 'one size fits all' pathway to circularity (e.g., E3.7).

Some circular strategies, although available as investment options in the game, were hardly mentioned in the eye-openers. Reverse logistics was only mentioned once, highlighting its uncertain outcome (E3.8), while substitution was only mentioned indirectly in one statement (E5.8).

3.2.3. Business Models and Entrepreneurship-How Can Circular Business Models Contribute to a Successful Business?

The quality that differentiates Risk\&RACE from other games on circular economy is its focus on the company perspective, the business strategy, and financial implications of adopting circular strategies. This aspect is clearly acknowledged in the reported eyeopeners, of which $60 \%$ were related to entrepreneurship, business models, business strategy, or financial considerations (Table 2). The number of statements per subtheme are provided in Table 3, including examples.

Twenty-seven players acknowledged the importance of investments when building a successful company. While observations of players during gameplay suggested that taking out loans was often perceived as a barrier for investments, many players mentioned in their eye-openers that they realised taking out a loan to finance an investment can be a smart idea (e.g., E2.24).

Investing in a circular business model was found to be especially challenging, since return on investment is typically to be sought in the long term, requiring strategic, long-term planning (22 statements). Still, twenty-seven statements indicated that circular business models can be profitable and reduce costs (e.g., E2.25). Especially in the case of a pay-peruse sales model, which ten players highlighted as an eye opener, revenues are delayed in time, but eventually can add up to higher profits than traditional sales (E1.28).

On the other hand, the complexity of setting up a circular business model was considered an important challenge by eleven players (e.g., E4.15). The need for collaboration with other parties (E4.16) and the importance of marketing to create a customer base (E3.15) were both only highlighted once.

Finally, the notion that 'entrepreneurship is about taking (and balancing) risks was mentioned in nine statements (e.g., 4.17). 


\subsection{Risk\&RACE as a Learning Tool on Circular Economy}

In the post-game surveys, all players made a self-assessment of their learning by indicating whether their understanding of certain business concepts (linked to the learning objective 'entrepreneurship') and circular economy concepts (linked to the learning objective 'circular economy') had improved or not (Figure 4).

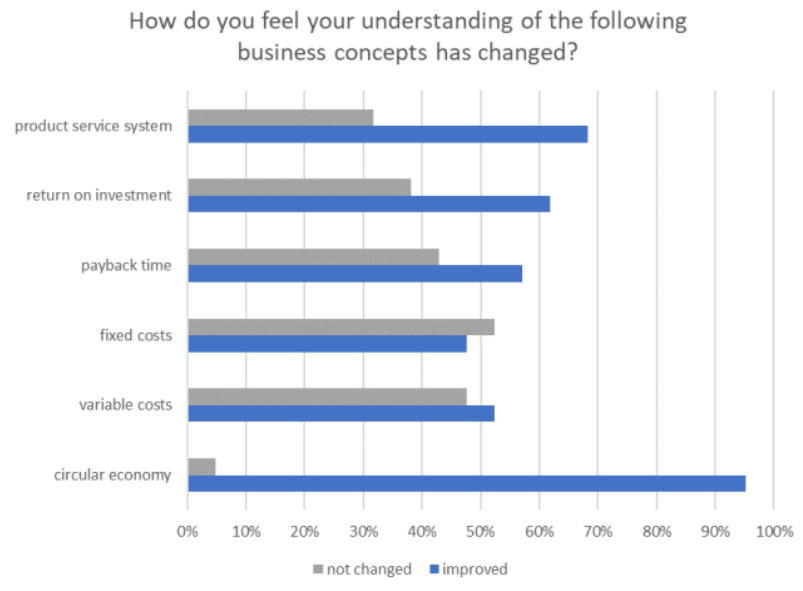

(a)

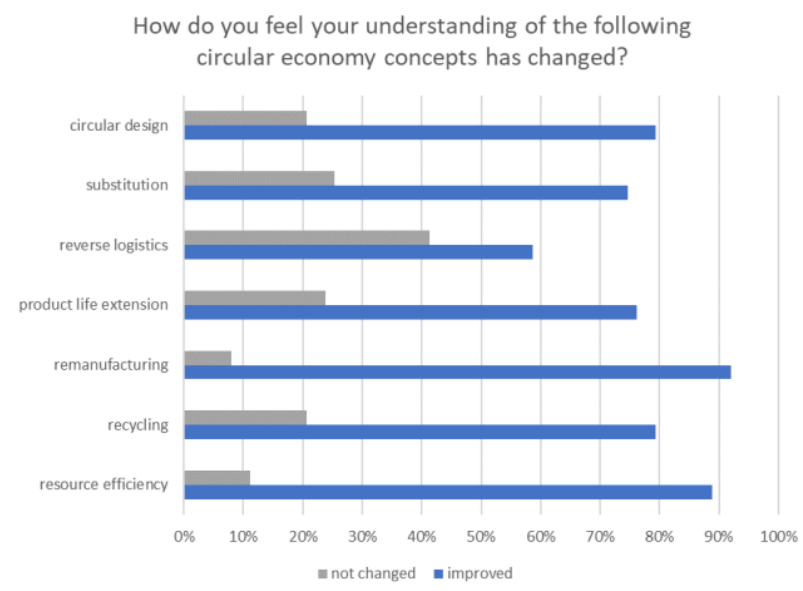

(b)

Figure 4. Self-assessment of the players' learning after playing Risk\&RACE $(n=63)$. (a) Business concepts; (b) Circular Economy Concepts.

In addition to their own learning experience, the players were invited to reflect upon the usefulness of the game as a learning tool (Table 4). Eighty-six percent of the responses about the tool were positive, highlighting that the game was interesting, fun and engaging, hands-on, and had a good connection with the real world. Twelve statements highlighted they found the game especially useful to introduce the concepts of circular economy (e.g., L5.4), also in a business context (L.5.3). Nine statements suggested that the learning would benefit from supplementary activities to deepen knowledge (e.g., L1.6). Four respondents praised the game's ability to prompt critical thinking and open up discussions among players about the merits and challenges of circular economy (e.g., 4.2).

Reflecting on the positive aspects of the learning experience, 31 players appreciated the game-approach itself, referring to specific game mechanics that made things tangible (e.g., S2.7, highlighting working with employees, money, and investments), its engaging fun-factor (e.g., S1.6), its competitiveness (e.g., S1.6), or its visualisations (e.g., S3.2). Many explicitly mentioned the need for strategic thinking (19 statements, e.g., S2.5) and the freedom to make their own decisions (e.g., S1.17) as strengths. Other elements that were often mentioned as assets are the uncertainty created by the scenario (nine statements, e.g., S1.2), the interaction with other players (10 statements, e.g., S1.11), and the connection with the real world (eight statements, e.g., S1.4). Fifteen statements explicitly referred to the educational value as an important strength (e.g., S4.4). The professionals in cohort 3 in particular mentioned that the game setting allowed them to freely experiment (five statements, e.g., S3.1).

Eight percent of respondents made negative statements about the game's suitability as a learning tool, pointing out they perceived the game as complex, time-consuming, and not sufficiently serious for academic purposes. When zooming in on the shortcomings, the game's complexity and elaborate game rules were highlighted most (22 statements, e.g., W4.10). At the same time, other participants criticised certain (over)simplifications and suggested improving the real-world connection by adding, for example, market demand dynamics, storage costs, or taxes (15 statements, e.g., W3.7). Finally, a more user-friendly bookkeeping was suggested (two statements, e.g., W5.6). Three players stated there were no weak points (e.g., W4.2). 
Table 4. Statements on Risk\&RACE as a learning tool.

\begin{tabular}{|c|c|c|}
\hline Themes & $\begin{array}{l}\text { Number of } \\
\text { Statements }\end{array}$ & Example Statements * \\
\hline \multicolumn{3}{|c|}{ Appreciation of Risk\&RACE as a learning tool } \\
\hline Interesting & 12 & $\begin{array}{c}\text { Great game that is challenging enough to trigger your interest and not too complicated so that } \\
\text { your ideas about circularity will always result in good learning." (L3.2) }\end{array}$ \\
\hline $\begin{array}{l}\text { Suitable as an } \\
\text { introduction }\end{array}$ & 12 & $\begin{array}{l}\text { Good tool to introduce business people and students to circular economy (L5.3) } \\
\text { Good as an introduction to new concepts. (L5.4) }\end{array}$ \\
\hline Fun and engaging & 11 & Useful and a lot of fun. (L2.6) \\
\hline $\begin{array}{l}\text { Need for complementing } \\
\text { activities }\end{array}$ & 9 & Good as a starter. Requires more in-depth study for a true understanding. (L1.6) \\
\hline Real world connection & 6 & "I think it is a very good game for simulating a business in real life." (L2.3) \\
\hline Hands-on & 5 & Very insightful, hands-on approach to learning some quite potentially confusing terms. (L1.4) \\
\hline Prompting discussion & 4 & "A fun way to discover CE, opening debate and discussion between colleagues." (L4.2) \\
\hline \multicolumn{3}{|l|}{ Strong elements } \\
\hline $\begin{array}{l}\text { Game mechanics and } \\
\text { design }\end{array}$ & 31 & $\begin{array}{l}\text { Layout was clear, topic was engaging. Friendly competitiveness made it fun. (S1.6) } \\
\text { The look of the game was attractive and it is very tangible with the employees, the money and } \\
\text { the investment cards. (S2.7) } \\
\text { [I liked the] concept behind the game and the visualisation about how circular product leasing } \\
\text { could work in practice (S3.2) }\end{array}$ \\
\hline Strategic thinking & 19 & You have to take risks to make a profit. Strategy is very determining for the result. (S2.5) \\
\hline Taking decisions & 15 & $\begin{array}{l}\text { The importance of decision-making and the time pressure while doing that. I also found quite } \\
\text { cool the connection to the real world. It allowed me to see better how decisions are made in } \\
\text { companies and how they justify them, which I hadn't understood clearly enough until } \\
\text { now. (S1.17) }\end{array}$ \\
\hline Educational elements & 15 & It improves knowledge of the various opportunities related to circular economy. (S4.4) \\
\hline $\begin{array}{l}\text { Interaction with other } \\
\text { players }\end{array}$ & 10 & $\begin{array}{l}\text { It was competitive, liked interacting with other players/teams, liked event cards and bonus } \\
\text { cards. (S1.11) }\end{array}$ \\
\hline $\begin{array}{l}\text { Uncertainty created by } \\
\text { scenario }\end{array}$ & 9 & $\begin{array}{l}\text { I liked that there was a new event each round, which required the players to make decisions } \\
\text { and try to anticipate what could happen in the future. (S1.2) }\end{array}$ \\
\hline Real-world connection & 8 & $\begin{array}{l}\text { Strategic and related to real life situations. I liked the event cards that gave each round a } \\
\text { different spin. (S1.4) }\end{array}$ \\
\hline Experimentation & 5 & We could take more risk, because of the unlimited cash and "it's only a game". (S3.1) \\
\hline \multicolumn{3}{|l|}{ Weak elements } \\
\hline $\begin{array}{l}\text { Complexity and rules } \\
\text { explanation }\end{array}$ & 22 & $\begin{array}{l}\text { It was too complicated so it took more time to really get involved. There are many too many } \\
\text { rules and some of them aren't obvious. It was also too long. (W4.10) }\end{array}$ \\
\hline (Over)simplifications & 15 & $\begin{array}{l}\text { Introduce storage costs, a predefined market demand that is not unlimited and maybe taxes, so } \\
\text { working with debts is more profitable. (W3.7) }\end{array}$ \\
\hline Game length & 9 & $\begin{array}{l}\text { It was quite lengthy with many rules-could be simplified for a more enjoyable } \\
\text { experience. (W1.8) }\end{array}$ \\
\hline Moderation & 4 & $\begin{array}{l}\text { Maybe some previous preparation especially for the game leader would be better as at the } \\
\text { beginning we made a few mistakes because no one knew what the right thing was. It would be } \\
\text { cool if a video was made with instructions that would be delivered to players prior to the } \\
\text { game. That way some more time would be spared to play } 4-5 \text { extra rounds. (W1.16) }\end{array}$ \\
\hline $\begin{array}{l}\text { Too little player } \\
\text { interaction }\end{array}$ & 3 & $\begin{array}{l}\text { There could have been more interaction with the other teams. We did this ourselves, but I } \\
\text { would have preferred it was more incorporated in the game. (W5.1) }\end{array}$ \\
\hline Bookkeeping & 2 & $\begin{array}{c}\text { Paper bookkeeping: an app would be better, for ecological reasons and to draw statistics } \\
\text { afterwards. (W5.6) }\end{array}$ \\
\hline Too limited debriefing & 1 & No learning tips at the end of the game. (W4.11) \\
\hline None & 3 & $\begin{array}{c}\text { None. (W4.2) } \\
\text { OK for me (W4.6) }\end{array}$ \\
\hline
\end{tabular}

* Code between brackets refers to the statements identifier; the first number corresponds to the cohort. 


\section{Discussion \\ 4.1. Cognitive Learning Outcomes of the Simulation Game}

A first goal of the Risk\&RACE simulation game was to transfer cognitive learnings about circular economy concepts in a business context. From the players' self-assessments (Figure 4), it can be concluded that between $60-90 \%$ of respondents reported an improvement, indicating that the understanding of circular economy concepts had increased as a result of the gaming experience. Regarding the learning about business concepts, players were less outspoken, with 50-70\% reporting an improvement, except in the case of the concept 'circular economy', which was labelled 'improved' by over $90 \%$. Since the accuracy of self-assessments to evaluate student learning and skill acquisition is often disputed [66] and a closed question on whether or not understanding is 'improved' provides little insight into the actual learning effects, these results are complemented by the players' responses to the open question on 'eye-openers'. This way, it can be investigated to what extent the game succeeded in conveying the intended learning goals on circular economy and entrepreneurship to the players. In addition to the validation of these overarching learning goals, a list of detailed learning outcomes can be synthesised and formulated based on the reported statements (Table 5).

Table 5. Overview of Risk\&RACE cognitive learning outcomes.

\begin{tabular}{|c|c|c|c|}
\hline & Intended Learning Goal & Achieved & Detailed Learning Outcomes \\
\hline \multirow{3}{*}{ (1) } & \multirow{3}{*}{$\begin{array}{l}\text { Understand the external pressures } \\
\text { that challenge the linear economy, } \\
\text { urging for a shift to a } \\
\text { circular economy }\end{array}$} & Yes & 1.1. The linear economy causes depletion of finite resources \\
\hline & & & $\begin{array}{l}\text { 1.2. Resource constraints cause uncertainty, making companies } \\
\text { vulnerable to unexpected events }\end{array}$ \\
\hline & & & 1.3. Linear economy creates a lot of waste \\
\hline \multirow{4}{*}{ (2) } & \multirow{4}{*}{$\begin{array}{l}\text { Explain the principles of various } \\
\text { circular economy strategies to make } \\
\text { a company circular, including their } \\
\text { advantages and disadvantages }\end{array}$} & Yes & 2.1. There are various strategies to make a company more circular \\
\hline & & & 2.2. Resource efficiency saves on resources and costs \\
\hline & & & $\begin{array}{l}\text { 2.3. Recycling is a valuable strategy to save resources, but still } \\
\text { causes losses in value and materials }\end{array}$ \\
\hline & & & $\begin{array}{l}\text { 2.4. Strategies that keep products in the loop, such as lifetime } \\
\text { extension or remanufacturing require deliberate product design }\end{array}$ \\
\hline \multirow{4}{*}{ (3) } & \multirow{4}{*}{$\begin{array}{l}\text { Reflect on how circular business } \\
\text { models can contribute to a } \\
\text { company's resilience and } \\
\text { profitability, as well as the barriers } \\
\text { to their implementation }\end{array}$} & Yes & $\begin{array}{l}\text { 3.1. Shifting to a circular business model requires long-term } \\
\text { planning and dedicated strategy }\end{array}$ \\
\hline & & & $\begin{array}{l}\text { 3.2. Circular business models, such as pay-per-use, can be } \\
\text { profitable, but focus on long term revenues }\end{array}$ \\
\hline & & & $\begin{array}{l}\text { 3.3. Circular business models can be complex and } \\
\text { capital-intensive to set up }\end{array}$ \\
\hline & & & 3.4. Entrepreneurship is about taking balanced risks \\
\hline
\end{tabular}

The game simulates external pressures using game mechanics that mimic resource scarcity and a real-world scenario, pre-set by the game moderator, representing a variety of factors that challenge a 'business-as-usual' linear way of doing business. Additional uncertainty is embedded using mechanisms such as dice-rolling to determine prices or access to resources at different points in the game. This setting of scarcity encourages (or even forces) players to rethink their business strategy and look for solutions in terms of changing product design or closing material loops in order to safeguard their resource supply and revenues. From the survey results, it is clear that the scarcity and uncertainty created by the game made players aware of the unsustainability of the linear economy and the need to rethink business in a more circular way. Many players explicitly referred to the unpredictability of the events and the need for strategic thinking as their favourite game features, illustrating how elements that increase motivation and engagement support cognitive learning [50]. To improve the realistic nature and the educational value of the 
game scenario, game moderators can create tailor-made scenarios and enrich the learning by reflecting on potential reasons for these price fluctuations and supply disruptions, such as geopolitical tensions, mining accidents, and market speculation. In this manner, the game experience can be intertwined with other instruction methods to deepen the learning $[35,67]$.

Various circular economy strategies are visualised using investment cards, symbols, and arrows on the player's board, adding to a better understanding of their effect on company operations [43]. Of all circular economy strategies included in the game, material efficiency, recycling, and remanufacturing were the most mentioned by the players, indicating that the game mainly succeeded in showing the merits and disadvantages of these strategies. At the same time, efficiency and recycling are the most common strategies used across industries today, as they are compatible with an essentially linear way of working and highly promoted by regulation [68]. This could explain why players were most acquainted with those strategies already and applied them more easily than lesser-known, but more 'inner circle', strategies such as lifetime extension, remanufacturing, or reverse logistics. Additionally, since lifetime extension and remanufacturing require the prior investment of circular design and since their merits only become obvious in the longer term, i.e., during the last few rounds of the game, some players did not get to the point when these investments would pay off before the game's end.

The observations on the use of the pay-per-use channel as well as the survey results indicate that Risk\&RACE is an effective educational tool to help understand the different dynamics of service models compared to sales models, as well as the relevance of payper-use models in enabling circular management of resources through manufacturing or recycling [69]. However, it should be noted that the business advantage of service models depends on resource price and availability together with the relative margins of such models compared to selling the product. In the workshops reported in this paper, the chosen scenario explicitly favoured service models over sales models. The flexibility of designing specific scenarios, however, enables educators to demonstrate the dependency of the success of certain business strategies typically labelled as "enabling the circular economy" on a favourable external environment, such as supporting environmental regulation [70].

While Risk\&RACE was designed to showcase the powers and drawbacks of circular economy strategies and business models, care has been taken not to be too obviously prescriptive, in line with self-determination theory [56]. Players were free to make their own decisions and could even pursue a fairly linear way of working far into the game. While many players praised their freedom to act and experiment, this had the disadvantage that not all players experienced all strategies available in the game. Some strategies may not even be used at all by any of the players. For example, 'reverse logistics' is a strategy that tended to be used less. In order to fill in these gaps and to ensure that accurate conclusions are drawn, it is crucial to complement the gameplay with a debriefing session. During the debriefing, players were encouraged to articulate their learnings, specific concepts can be clarified, trade-offs can be discussed, and real-life examples can be added to make insights more tangible and support the integration of new knowledge with prior knowledge [35].

\subsection{Affective Outcomes Induced by the Simulation Game}

A second goal of the Risk\&RACE game was to create an engaging educational tool that encourages players to reflect on their behaviour through experimentation, interaction, and discussion.

From the survey results, it is clear that the vast majority of players enjoyed the game experience. They referred to it as being 'interesting', 'engaging', and 'fun', indicating that the game contributes to intrinsic motivation and the creation of 'flow' [57]. While the self-assessment indicated that most players perceived an improvement in their knowledge about circular economy concepts and business models, it was mainly the ability to train cognitive skills, such as decision making, strategic thinking, and long-term planning that was mentioned as an important feature adding to the quality of the game as a learning 
tool. In-game cognitive learning relies on a combination of one's own experimentation, observation of the strategies of other players, and linking new insights to existing prior knowledge and real-world examples, in line with constructivist learning theory [58].

As witnessed from the variety of strategies followed by the players across all workshops, the game offers a large degree of autonomy for players in making strategic decisions on which circular investments to prioritise in a given situation. This is in contrast to classical learning tools such as lectures or textbooks, where learners often remain passive and circular strategies are typically explained from an environmental perspective and disconnected from a business and societal context. The simulation game design of Risk\&RACE explicitly encourages participants to connect different circular economy concepts (technologies such as recycling or remanufacturing, product-service systems, reverse logistics, etc.) in a way that they think will be the best way to respond to the external business context enforced by the scenario. By experiencing the direct consequences of their decisions in the simulated context, a more tangible learning effect is realized compared with other, passive educational tools. This could be confirmed by the survey results, showing that the players' freedom to make their own strategic decisions and experience their effects was perceived as motivating and exciting, in line with self-determination theory [56].

Furthermore, observations showed that in response to external forces or in search for higher long-term profits, lively discussions within teams emerged about the advantages and disadvantages of different strategic choices. As a result, many players gradually switched to a more circular way of working by changing their product design, sales model (partly or fully), or both. The occurrence of such regular moments of self-questioning and reflecting on the strategies used can increase the level of deep knowledge, while at the same time retaining player engagement [35].

The in-game collaboration with a teammate, in combination with a group debriefing during which players' strategies are discussed, encourage players to make explicit their tacit views [71] about risk-management, priority-setting, short-term vs. long-term profitability, and producer responsibility to create sustainable products. By helping players to reflect on their actions and to articulate the reasons behind their decisions, Risk\&RACE helps players to gain a deeper understanding of their drivers and barriers, raises awareness of the sustainability impacts of their decisions, and encourages them to explore new solutions. By giving a debriefing, the game moderator encourages participants not only to explicitly articulate their own learning outcomes, but also to learn from the experiences of others [28] and to integrate these new insights into prior knowledge and personal views on entrepreneurship and sustainability [35].

\subsection{The Simulation Game as a Learning Tool}

The main shortcomings impairing the game's effectiveness as a learning tool are its initial complexity, necessitating rather elaborate playing instructions. In cohort 1 , where the full game explanation was given in a plenary session and student volunteers were assigned to guide the gameplay, lengthiness of the game explanation and the lack of proper game moderation were reported more often in the surveys compared with the other cohorts, indicating that the guidance of a skilled game moderator at the table is crucial to assure smooth gameplay. Additionally, such a moderator plays an important role in deepening understanding by connecting game situations to the real world, adding to greatly to the learning experience.

Depending on the details of the game scenario, certain strategies may prove to be more successful than others. In the resource-constraint scenario that was used for all cohorts described in this paper, the strategy that proved to be most successful for winning the game was to invest early in circular design, sell through a pay-per-use system made more profitable by life-time extension, and close the loop using remanufacturing. However, while the shift to circular economy is obviously encouraged by multiple mechanics forming part of the game's backbone, using another scenario could lead to other player strategies 
and different outcomes, making Risk\&RACE a powerful and versatile simulation tool, e.g., in combination with scenario planning.

Overall, the results highlighted that the game design captures a good balance between sufficient complexity to convey the cognitive learning outcomes with appropriate nuance, and sufficient simplicity to keep the gameplay understandable and engaging so players stay motivated and continue experimenting (affective outcomes). As a result of achieving this balance, the game does ignore several important business factors and dynamics, such as transportation and warehousing costs, product demand dynamics, market competition between players, and the uncertainties regarding perceived value of recycled or remanufactured products - which is often brought up as an important market barrier to circular economy [72,73]. This highlights the importance of a post-game debriefing, during which such elements can be brought into the educational discussion.

\section{Conclusions}

Circular economy is a complex topic to teach. The aim of this paper was to assess the merits of the game Risk\&RACE to educate students and entrepreneurs about the relevance and effects of circular strategies at the business level. Through observation of players' strategies during the game and their responses to a survey after the gameplay, the transfer of the intended cognitive learning goals as well as the creation of a highly motivational and experimental learning environment could be confirmed. Moreover, typical combinations of investment strategies could be observed across workshops, indicating that Risk\&RACE revealed players' underlying views about entrepreneurship, resource use, and circular economy, while the interactive game setting encouraged them to articulate, challenge, and discuss these views with their peers. This makes Risk\&RACE a rich educational tool to convey complex messages about circular entrepreneurship, such as the links between different circular strategies and business models, trade-offs between different strategies, and how entrepreneurs can use circular strategies to adapt to resource constraints resulting from external forces. Moreover, the freedom of making their own strategic decisions from a myriad of possibilities and within a set of constraints induced by the scenario prompted lively discussions between teammates, competing teams, and with the moderator. This creates an engaging learning environment in which players are encouraged to make their personal views explicit, ask questions, and reflect on their decisions.

Serious games are often praised as being more effective than conventional instruction methods because they increase the learner's engagement, encourage experimentation, and train critical thinking and problem-solving skills. This was confirmed. However, as discussed by Wouters et al. [35] and Sitzmann [67], if educational games are supplemented with other instruction methods and group learning, learning gains will be greater. A post-game group debriefing, in which players reflect on the reasons behind their actions and articulate their learning outcomes rather than attributing their actions to intuition, allows players to achieve a deeper understanding of mechanisms and concepts and learn from each other, while encouraging them to discuss the translation of learning outcomes into implementable insights that can be applied in practice.

Some directions for further study can be identified. Concerning the effectiveness of the game as a learning tool, different aspects could be explored further. Firstly, learning outcomes from the game workshop could be compared with conventional instruction methods on circular economy. However, as indicated by Connolly et al. [40], the design of such randomised controlled experiments is challenging. Secondly, differences in learning outcomes and experiences between different target audiences (i.e., students and business executives) could be investigated in more detail. This would require additional workshops as the current amount of data did not suffice to deduce significant conclusions from such a comparison. Thirdly, the long-term effectiveness of the learning experience could be investigated. The post-game surveys were completed immediately or shortly after the gameplay. While this ensured a high response rate, it also created a focus on short-term learning effects. To monitor long-term retention of learning outcomes, a delayed survey 
conducted a few months after the game experience could uncover the deeper learning outcomes that were retained in the long term. Additionally, a follow-up of the participants after the game workshop would allow monitoring of the extent to which learning outcomes gained from the game have crystallised into further insights or concrete actions in players personal behaviour or in a company context.

Concerning the practical application of serious games in start-up coaching, business consulting, and strategic company planning, different approaches could be explored. While the present research used the game in a stand-alone 'introductory' workshop for a broad audience, it also has potential to be used in courses of longer duration or coaching programmes aimed at entrepreneurs, intrapreneurs, or business executives looking to create or transition towards a more sustainable, circular business. In such a setting, a well-informed tailoring of the game scenario to the appropriate product or sector could potentially introduce more specific insights relevant to the participants' context. Additionally, the action focus would shift from 'introducing concepts' towards the translation of game learning outcomes into implementable ideas, relevant business experiments, and practical roadmaps with concrete milestones.

Author Contributions: Conceptualization, S.M. and J.G.; methodology, S.M.; data collection, S.M. and J.G.; formal analysis, S.M.; writing—original draft preparation, S.M. and J.G.; writing-review and editing, S.M.; visualization, S.M.; supervision, S.M.; project administration, S.M.; funding acquisition, S.M. All authors have read and agreed to the published version of the manuscript.

Funding: The pilot version of Risk\&RACE was developed in partnership with VITO, TU Delft, In the loop Games, VTT, and Wuppertal Institute, and received funding from the European Institute of Innovation and Technology (EIT), a body of the European Union, under Horizon 2020, the EU Framework Programme for Research and Innovation [Project 15021 FOSTER-ERM]. The final version of Risk\&RACE, presented in this paper, was developed by VITO.

Institutional Review Board Statement: Ethical review and approval were waived for this study, due to the following reasons: (1) The research did not target any vulnerable groups. (2) The aims of the research were clearly stated to the participants, and no form of deception was involved in the test setup. (3) Participation to the research surveys was entirely voluntary and not linked to any reward or adverse consequence on those players that refused to participate. (4) The research did not entail any activities that would result in any form of risk, pain, anxiety, physical or psychological stress for the participants. (5) No sensitive data were gathered or processed, all results were reported anonymously.

Informed Consent Statement: Informed consent was obtained from all subjects involved in the study.

Data Availability Statement: The data presented in this study are available on request from the corresponding author.

Acknowledgments: We would like to thank all students and professionals who engaged in playing Risk\&RACE and spent the time to voluntarily complete the survey to feed into this study. Finally, we want to say a very special 'thank you' to Claude Nuyts, who was the visionary and driving force behind the initial development of Risk\&RACE.

Conflicts of Interest: The authors declare no conflict of interest. The funders had no role in the design of the study; in the collection, analyses, or interpretation of data; in the writing of the manuscript, or in the decision to publish the results.

\section{Appendix A. Risk\&RACE Gameplay}

Appendix A.1. Aim

Risk\&RACE is a moderated board game in which players inherit a production company in a world that is facing material scarcity and volatile markets. Their goal is to increase their company value in the timeframe of 10 rounds, representing 10 years. To respond to the challenges imposed upon them, players will need to rethink their material supply chain, product design, sales strategy, and product end-of-life. At the end of the game, the player with the highest company value wins. Company value is determined by a combined 
scoring of the player's cash and debt position, investments, material and product stocks, and number of employees.

\section{Appendix A.2. Setup}

The game can be played with three or four players (or teams of two), guided by a game moderator. The game takes about $3 \mathrm{~h}$ to play and should be complemented with a debriefing to articulate and discuss learning outcomes. At the start of the game, players have a standard product design, a starting capital, some debt, some material stock, and four employees. To highlight the financial implications of business decisions and circular strategies, the game relies on money and simplified bookkeeping to quantify fixed costs, variable (material) costs, investments, employee training costs, and revenues.

\section{Appendix A.3. Game Scenario}

Players need to take their business decisions against a pre-defined scenario of ten events, prepared by the game moderator. These events mimic political, economic, social or technological developments or pressures (in management literature, these external factors are often studied using the PEST framework [74]) that are regarded as drivers for the circular economy, for example, resource constraints, price fluctuations (e.g., depending on dice rolls), changing market demand, new available technologies or product regulations.

\section{Appendix A.4. Round Sequence}

The game consists of ten rounds in which players play simultaneously. Each round has twelve stages in a fixed order (Figure A1), starting with an 'Event' and the payment of 'Fixed costs' (labour and interest). Next, players assign their workers to a set of tasks, which are performed in a fixed order in the remaining stages, such as 'investing', 'buying materials', 'producing' and 'selling'. Materials need to be purchased from a (finite) resource market, products are made according to a pre-set design and there are two sales options: ownership or pay-per-use (i.e., a simplified representation of a product-service system [75]). Products sold in ownership generate direct full revenues, but end up in the urban mine at end-of-life, making the wastefulness of the linear 'make-take-dispose paradigm' tangible [76]. Products sold in pay-per-use generate delayed, lower revenues spread over multiple rounds, but remain the property of the company and automatically return as used products after their last use.

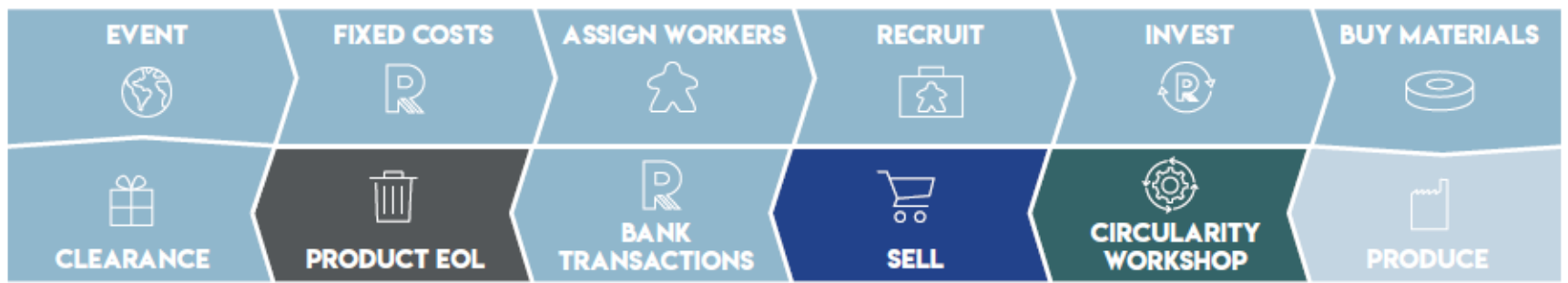

Figure A1. Round sequence.

While all players start off with the same product design, there are several options to change into an alternative, more material-efficient or circular design by making the corresponding investments. Similarly, other investments allow players to increase their production capacity, extend product lifetimes, take back end-of-life products from the market, recycle materials or remanufacture used products (Table A1). Players can also pay to recruit additional workers, which increases the number of actions they can perform in the next rounds. 
Table A1. Overview of Risk\&RACE investment options and their manifestation in the game mechanics.

\begin{tabular}{|c|c|c|}
\hline Investment & Advantage in the Game & Trade-Offs and Disadvantages \\
\hline Material efficiency & $\begin{array}{l}\text { Reduces the amount of materials that are } \\
\text { needed to make a product }\end{array}$ & Reduces efficiency of recycling \\
\hline Material substitution & $\begin{array}{l}\text { Enables players to exchange a material } \\
\text { type for a cheaper, renewable or less } \\
\text { scarce material }\end{array}$ & Substituting materials can also be limited \\
\hline Reverse logistics & $\begin{array}{l}\text { Allows players to take back products sold } \\
\text { in ownership before they become waste }\end{array}$ & $\begin{array}{l}\text { It is uncertain how many used products are } \\
\text { effectively returned. }\end{array}$ \\
\hline Recycling & $\begin{array}{l}\text { Makes it possible to recover materials } \\
\text { from end-of-life products, regardless of } \\
\text { their design }\end{array}$ & $\begin{array}{l}\text { Considerable process inefficiencies cause material } \\
\text { loss, and recycled materials can only be used in the } \\
\text { next round, causing delay }\end{array}$ \\
\hline Product life extension & $\begin{array}{l}\text { Supports the longer use of products, } \\
\text { yielding additional revenues } \\
\text { in pay-per-use }\end{array}$ & $\begin{array}{l}\text { Requires the investment Circular design as a } \\
\text { prerequisite and lengthens the time before a } \\
\text { product can be recycled or remanufactured }\end{array}$ \\
\hline Remanufacturing & $\begin{array}{l}\text { Supports the disassembly and } \\
\text { remanufacturing of take-back products, } \\
\text { avoiding primary production costs and } \\
\text { shortening production time }\end{array}$ & $\begin{array}{l}\text { Requires the investment Circular design as a } \\
\text { prerequisite; requires skilled labour }\end{array}$ \\
\hline Circular design & $\begin{array}{l}\text { Enables Product life extension and } \\
\text { Remanufacturing }\end{array}$ & $\begin{array}{l}\text { Does not improve circularity or increase revenues } \\
\text { by itself, but needs to be complemented by } \\
\text { end-of-life strategies such as product life extension } \\
\text { or remanufacturing. }\end{array}$ \\
\hline 2nd production line & Increases production capacity & $\begin{array}{l}\text { Applicability is highly vulnerable to supply } \\
\text { disruptions and resource constraints }\end{array}$ \\
\hline
\end{tabular}

In the 'bank transactions' stage, near the end of each round, players pay or receive their net costs or revenues from the bank. When players have insufficient cash to pay their costs, they receive a loan from the bank on which interest has to be paid. Vice versa, if players have earned sufficient money, they can pay back loans to reduce their interest burden.

At the end of each round, all workers return to their company to get ready for the next round and their next task. Players receive a bonus card which offers them a one-time advantage, such as an investment subsidy, improved access to materials or additional product revenue.

\section{Appendix A.5. End of the Game}

The game ends after ten rounds. Company value is determined by a combined scoring of a player's cash and debt position, number of investments, value of remaining stocks of materials, new and used products, and number of employees.

\section{Appendix B. Survey Questions}

1. After having played Risk\&RACE, what are the main lessons or eye-openers you experienced?

2. Now that you have played, for each term/concept presented below, please select to what extent playing the game has affected your understanding of the term/concept. 
Business-Related Terms:

\begin{tabular}{c}
\hline After Playing the Game, I Feel My Understanding of the Term/Concept Has: \\
\hline Improved Not Changed \\
\hline Fixed cost \\
\hline Variable cost \\
\hline Free cash flow \\
\hline Payback time \\
\hline Return on investment \\
\hline Product service systems \\
\hline Circular Economy \\
\hline
\end{tabular}

\section{Resource-Related Terms:}

\begin{tabular}{l}
\hline \multicolumn{1}{c}{ After Playing the Game, I Feel My Understanding of The Term/Concept Has: } \\
\hline Improved Not Changed \\
\hline Circular design \\
\hline Resource efficiency \\
\hline Recycling \\
\hline Remanufacturing \\
\hline Product life extension \\
\hline Reverse logistics \\
\hline Substitution \\
\hline
\end{tabular}

3. Please indicate which aspects you liked about Risk\&RACE?

4. Please indicate which aspects you didn't like or would like to see improved?

5. What is your overall impression of Risk\&RACE as a learning tool on circular economy strategies and business models?

\section{References}

1. Steffen, W.; Richardson, K.; Rockström, J.; Cornell, S.E.; Fetzer, I.; Bennett, E.M.; Biggs, R.; Carpenter, S.R.; De Vries, W.; De Wit, C.A.; et al. Planetary boundaries: Guiding human development on a changing planet. Science 2015, 347, 1259855. [CrossRef]

2. Circle Economy. Jobs and Skills in the Circular Economy. 2020. Available online: https:/ /assets.website-files.com/5d26d80e883 6af2d12ed1269/5e6897dafe8092a5a678a16e_202003010\%20-\%20J\%26S\%20in\%20the\%20circular\%20economy\%20report\%20-\% 20297x210.pdf (accessed on 2 April 2020).

3. Ellen MacArthur Foundation. Growth within: A Circular Economy Vision for a Competitive Europe. Ellen MacArthur Foundation Publishing. 2015. Available online: https:/ / www.ellenmacarthurfoundation.org/assets/downloads/publications/ EllenMacArthurFoundation_Growth-Within_July15.pdf (accessed on 9 October 2020).

4. European Commission. A New Circular Economy Action Plan for a Cleaner and More Competitive Europe COM/2020/98 Final 2020; European Comission: Brussels, Belgium, 2020.

5. Rizos, V.; Behrens, A.; Drabik, E.; Rinaldi, D.; Tuokko, K. Role of Business in the Circular Economy: Markets, Processes and Enabling Policies; Report of a CEPS Task Force; Centre for European Policy Studies: Brussels, Belgium, 2016.

6. Salvador, R.; Barros, M.V.; da Luz, L.M.; Piekarski, C.M.; de Francisco, A.C. Circular business models: Current aspects that influence implementation and unaddressed subjects. J. Clean. Prod. 2019, 250, 119555. [CrossRef]

7. Business Europe. Circulary—Circular Economy Industry Platform. Available online: http:/ /www.circulary.eu/sectors (accessed on 9 October 2020).

8. Circulator Home-Circulator. Available online: http://circulator.eu/ (accessed on 9 October 2020).

9. Ellen MacArthur Foundation. Circular Economy Case Studies. Available online: https:/ / www.ellenmacarthurfoundation.org/ case-studies (accessed on 9 October 2020). 
10. Linder, M.; Williander, M. Circular Business Model Innovation: Inherent Uncertainties. Bus. Strat. Environ. 2015, 26, 182-196. [CrossRef]

11. Tura, N.; Hanski, J.; Ahola, T.; Ståhle, M.; Piiparinen, S.; Valkokari, P. Unlocking circular business: A framework of barriers and drivers. J. Clean. Prod. 2018, 212, 90-98. [CrossRef]

12. Ghisellini, P.; Cialani, C.; Ulgiati, S. A Review on Circular Economy: The Expected Transition to a Balanced Interplay of Environmental and Economic Systems. J. Clean. Prod. 2016, 114, 11-32. [CrossRef]

13. Kirchherr, J.; Piscicelli, L.; Bour, R.; Kostense-Smit, E.; Muller, J.; Huibrechtse-Truijens, A.; Hekkert, M. Barriers to the Circular Economy: Evidence from the European Union (EU). Ecol. Econ. 2018, 150, 264-272. [CrossRef]

14. Stahel, W.R. Policy for material efficiency-Sustainable taxation as a departure from the throwaway society. Philos. Trans. R. Soc. A Math. Phys. Eng. Sci. 2013, 371, 20110567. [CrossRef] [PubMed]

15. Bocken, N.M.P.; Ritala, P.; Huotari, P. The Circular Economy: Exploring the Introduction of the Concept Among S\&P 500 Firms. J. Ind. Ecol. 2017, 21, 487-490. [CrossRef]

16. WBCSD. 8 Business Cases for the Circular Economy. Available online: https://www.wbcsd.org/Programs/Circular-Economy/ Factor-10/Resources / 8-Business-Cases-to-the-Circular-Economy (accessed on 9 October 2020).

17. Bocken, N.; Short, S. Towards a sufficiency-driven business model: Experiences and opportunities. Environ. Innov. Soc. Transitions 2015, 18, 41-61. [CrossRef]

18. Lewandowski, M. Designing the business models for circular economy-Towards the conceptual framework. Sustainability 2016, 8, 43. [CrossRef]

19. Geissdoerfer, M.; Vladimirova, D.; Evans, S. Sustainable business model innovation: A review. J. Clean. Prod. 2018, 198, 401-416. [CrossRef]

20. Guldmann, E.; Huulgaard, R.D. Barriers to circular business model innovation: A multiple-case study. J. Clean. Prod. 2019, 243, 118160. [CrossRef]

21. Pieroni, M.P.P.; McAloone, T.C.; Pigosso, D.C.A. Business model innovation for circular economy and sustainability: A review of approaches. J. Clean. Prod. 2019, 215, 198-216. [CrossRef]

22. De Jesus, A.; Mendonça, S. Lost in Transition? Drivers and Barriers in the Eco-innovation Road to the Circular Economy. Ecol. Econ. 2018, 145, 75-89. [CrossRef]

23. Lieder, M.; Rashid, A. Towards circular economy implementation: A comprehensive review in context of manufacturing industry. J. Clean. Prod. 2016, 115, 36-51. [CrossRef]

24. Roobeek, A.; de Ritter, M. Rethinking Business Education for Relevance in Business and Society in Times of Disruptive Change. In Proceedings of the AoM, Anaheim, CA, USA, 5-9 August 2016.

25. Bocken, N.; Schuit, C.; Kraaijenhagen, C. Experimenting with a circular business model: Lessons from eight cases. Environ. Innov. Soc. Transit. 2018, 28, 79-95. [CrossRef]

26. Moreno, M.; De Los Rios, C.; Rowe, Z.; Charnley, F. A Conceptual Framework for Circular Design. Sustainability 2016, 8, 937. [CrossRef]

27. Chappin, E.J.; Bijvoet, X.; Oei, A. Teaching sustainability to a broad audience through an entertainment game-The effect of Catan: Oil Springs. J. Clean. Prod. 2017, 156, 556-568. [CrossRef]

28. Whalen, K.A.; Berlin, C.; Ekberg, J.; Barletta, I.; Hammersberg, P. 'All they do is win': Lessons learned from use of a serious game for Circular Economy education. Resour. Conserv. Recycl. 2018, 135, 335-345. [CrossRef]

29. Coursera Circular Economy—Sustainable Materials Management. Available online: https://www.coursera.org/learn/circulareconomy (accessed on 2 April 2021).

30. EdX Circular Economy: An Introduction. Available online: https:/ / www.edx.org/course/circular-economy-an-introduction (accessed on 2 April 2021).

31. Ellen MacArthur Foundation a Global Snapshot of Circular Economy Learning Offerings in Higher Education. Available online: https:/ /indd.adobe.com/view/0a75325c-0a0f-4c57-8868-4bf550bc4e66 (accessed on 4 February 2021).

32. Bocken, N.; Strupeit, L.; Whalen, K.; Nußholz, J. A Review and Evaluation of Circular Business Model Innovation Tools. Sustainability 2019, 11, 2210. [CrossRef]

33. Qian, M.; Clark, K.R. Game-based Learning and 21st century skills: A review of recent research. Comput. Hum. Behav. 2016, 63, 50-58. [CrossRef]

34. Bevilacqua, M.; Ciarapica, F.E.; Mazzuto, G.; Paciarotti, C. “Cook \&Teach”: Learning by playing. J. Clean. Prod. 2015, $106,259-271$. [CrossRef]

35. Wouters, P.; Van Nimwegen, C.; Van Oostendorp, H.; Van Der Spek, E.D. A meta-analysis of the cognitive and motivational effects of serious games. J. Educ. Psychol. 2013, 105, 249-265. [CrossRef]

36. Kolb, D.A. Experiential Learning: Experience as the Source of Learning and Development; Prentice Hall: Englewood Cliffs, NJ, USA, 1984.

37. Gatti, L.; Ulrich, M.; Seele, P. Education for sustainable development through business simulation games: An exploratory study of sustainability gamification and its effects on students' learning outcomes. J. Clean. Prod. 2018, 207, 667-678. [CrossRef]

38. Whalen, K. Risk \& Race: Creation of a finance-focused circular economy serious game. In PLATE: Product Lifetimes and the Environment-Conference Proceedings of PLATE 2017, Delft, The Netherlands, 8-10 November 2017; Delft University of Technology and IOS Press: Amsterdam, The Netherlands, 2017; Volume 9, pp. 422-425. [CrossRef] 
39. Clark, D.B.; Tanner-Smith, E.E.; Killingsworth, S.S. Digital Games, Design, and Learning. Rev. Educ. Res. 2016, 86, 79-122. [CrossRef] [PubMed]

40. Connolly, T.M.; Boyle, E.A.; MacArthur, E.; Hainey, T.; Boyle, J.M. A systematic literature review of empirical evidence on computer games and serious games. Comput. Educ. 2012, 59, 661-686. [CrossRef]

41. Fu, K.; Hainey, T.; Baxter, G. A Systematic Literature Review to Identify Empirical Evidence on the Use of Computer Games in Business Education and Training. In Proceedings of the 10th European Conference on Games Based Learning, Scotland, UK, 6-7 October 2016; Volume 1, pp. 232-239.

42. Vlachopoulos, D.; Makri, A. The effect of games and simulations on higher education: A systematic literature review. Int. J. Educ. Technol. High. Educ. 2017, 14, 22. [CrossRef]

43. Fjællingsdal, K.S.; Klöckner, C.A. Green across the Board: Board Games as Tools for Dialogue and Simplified Environmental Communication. Simul. Gaming 2020, 51, 632-652. [CrossRef]

44. Abt, C.C. Serious Games; Viking Press: New York, NY, USA, 1970.

45. Gómez, R.L.; Suárez, A.M. Gaming to succeed in college: Protocol for a scoping review of quantitative studies on the design and use of serious games for enhancing teaching and learning in higher education. Int. J. Educ. Res. Open 2020, 2, 100021. [CrossRef]

46. Zhonggen, Y. A Meta-Analysis of Use of Serious Games in Education over a Decade. Int. J. Comput. Games Technol. 2019, 2019, 1-8. [CrossRef]

47. de la Torre, R.; Onggo, B.; Corlu, C.; Nogal, M.; Juan, A. The Role of Simulation and Serious Games in Teaching Concepts on Circular Economy and Sustainable Energy. Energies 2021, 14, 1138. [CrossRef]

48. Douglas, B.D.; Brauer, M. Gamification to prevent climate change: A review of games and apps for sustainability. Curr. Opin. Psychol. 2021, 42, 89-94. [CrossRef] [PubMed]

49. Zainuddin, Z.; Chu, S.K.W.; Shujahat, M.; Perera, C.J. The impact of gamification on learning and instruction: A systematic review of empirical evidence. Educ. Res. Rev. 2020, 30, 100326. [CrossRef]

50. Krath, J.; Schürmann, L.; von Korflesch, H.F. Revealing the theoretical basis of gamification: A systematic review and analysis of theory in research on gamification, serious games and game-based learning. Comput. Hum. Behav. 2021, 125, 106963. [CrossRef]

51. Haskell, C.C. Design Variables of Attraction in Quest-Based Learning. Ph.D. Thesis, Boise State University, Boise, ID, USA, 2012.

52. Malone, T.W. Toward a Theory of Intrinsically Motivating Instruction*. Cogn. Sci. 1981, 5, 333-369. [CrossRef]

53. Chen, C.-H.; Liu, J.-H.; Shou, W.-C. How Competition in a Game-Based Science Learning Environment Influences Students Learning Achievement, Flow Experience, and Learning Behavioral Patterns. J. Educ Technol. Soc. 2018, 21, 164-176.

54. Van Der Meij, H.; Albers, E.; Leemkuil, H.H. Learning from games: Does collaboration help? Br. J. Educ. Technol. 2010, 42, 655-664. [CrossRef]

55. Boyle, E.; Connolly, T.M.; Hainey, T. The role of psychology in understanding the impact of computer games. Entertain. Comput. 2011, 2, 69-74. [CrossRef]

56. Ryan, R.M.; Deci, E.L. Self-determination theory and the facilitation of intrinsic motivation, social development, and well-being. Am. Psychol. 2000, 55, 68-78. [CrossRef]

57. Csikszentmihalyi, M. Beyond Boredom and Anxiety; Jossey-Bass: San Francisco, CA, USA, 2000; ISBN 978-0-7879-5140-5.

58. Easley, J.A.; Piaget, J.; Rosin, A. The Development of Thought: Equilibration of Cognitive Structures. Educ. Res. 1978, 7, 18. [CrossRef]

59. Wouters, P.; van der Spek, E.D.; van Oostendorp, H. Current Practices in Serious Game Research. Games-Based Learn. Adv. Multi-Sens. Hum. Comput. Interfaces Tech. Eff. Pract. 2009, 34, 232-250. [CrossRef]

60. Lawton, K.; Carter, C.; Lee, J.; Tan, A.; de Prado, A.; Luscombe, D.; Briscoe, S. The Opportunities to Business of Improving Resource Efficiency; Final Report; European Commission: Brussels, Belgium, 2013; p. 123.

61. Bocken, N.M.P.; de Pauw, I.; Bakker, C.; van der Grinten, B. Product design and business model strategies for a circular economy. J. Ind. Prod. Eng. 2016, 33, 308-320. [CrossRef]

62. Nußholz, J.L.K. Circular Business Models: Defining a Concept and Framing an Emerging Research Field. Sustainability 2017, 9, 1810. [CrossRef]

63. Linneberg, M.S.; Korsgaard, S. Coding qualitative data: A synthesis guiding the novice. Qual. Res. J. 2019, 19, 259-270. [CrossRef]

64. Reim, W.; Parida, V.; Örtqvist, D. Product-Service Systems (PSS) business models and tactics-A systematic literature review. J. Clean. Prod. 2015, 97, 61-75. [CrossRef]

65. Stahel, W.R. The Performance Economy, 2nd ed.; Palgrave-MacMillan: London, UK, 2010. [CrossRef]

66. Andrade, H.L. A Critical Review of Research on Student Self-Assessment. Front. Educ. 2019, 4. [CrossRef]

67. Sitzmann, T. A meta-analytic examination of the instructional effectiveness of computer-based simulation games. Pers. Psychol. 2011, 64, 489-528. [CrossRef]

68. Garcés-Ayerbe, C.; Rivera-Torres, P.; Suárez-Perales, I.; Leyva-De La Hiz, D.I. Is It Possible to Change from a Linear to a Circular Economy? An Overview of Opportunities and Barriers for European Small and Medium-Sized Enterprise Companies. Int. J. Environ. Res. Public Health 2019, 16, 851. [CrossRef]

69. Pieroni, M.D.P.; Blomsma, F.; McAloone, T.C.; Pigosso, D.C.A. Enabling circular strategies with different types of product/servicesystems. Procedia CIRP 2018, 73, 179-184. [CrossRef]

70. Urbinati, A.; Rosa, P.; Sassanelli, C.; Chiaroni, D.; Terzi, S. Circular business models in the European manufacturing industry: A multiple case study analysis. J. Clean. Prod. 2020, 274, 122964. [CrossRef] 
71. Van Haaften, M.A.; Lefter, I.; Lukosch, H.; Van Kooten, O.; Brazier, F. Do Gaming Simulations Substantiate That We Know More Than We Can Tell? Simul. Gaming 2020, 52, 478-500. [CrossRef]

72. Hamzaoui-Essoussi, L.; Linton, J.D. Offering branded remanufactured/recycled products: At what price? J. Remanuf. 2014,4 , 24. [CrossRef]

73. Yu, S.; Lee, J. The Effects of Consumers' Perceived Values on Intention to Purchase Upcycled Products. Sustainability 2019, 11, 1034. [CrossRef]

74. McGee, J.; Sammu-Bonnici, T. Wiley Encyclopedia of Management: Strategic Management; John Wiley \& Sons: Hoboken, NJ, USA, 2015; Volume 12, ISBN 978-1-119-97251-8.

75. Tukker, A. Product services for a resource-efficient and circular economy-A review. J. Clean. Prod. 2015, 97, 76-91. [CrossRef]

76. Ellen MacArthur Foundation. Towards the Circular Economy: Economic and Business Rationale for an Accelerated Transition. Available online: https: / www.ellenmacarthurfoundation.org/assets/downloads/publications/Ellen-MacArthur-FoundationTowards-the-Circular-Economy-vol.1.pdf (accessed on 21 June 2020). 